\title{
Chronic undernutrition in pregnancy and lactation
}

\author{
BY JANE A. KUSIN ${ }^{1}$, SRI KARDJATI ${ }^{2}$ AND U. H. RENQVIST ${ }^{1}$ \\ ${ }^{1}$ Royal Tropical Institute, Amsterdam, The Netherlands and ${ }^{2}$ Nutrition Laboratories, School of \\ Medicine, Airlangga University, Surabaya, Indonesia
}

Based on the dietary energy supply per person per $\mathrm{d}$ and a minimum energy requirement of $1.4 \times$ basal metabolic rate (BMR), it is estimated that $11-32 \%$ of adults in developing countries were undernourished (Food and Agriculture Organization, 1990). Even if adequate amounts of food are available, unequal food distribution favouring men over women and cultural taboos may restrict food intake of women. Since they are usually engaged in productive activities which entail a substantial energy expenditure (McGuire \& Popkin, 1989), it is likely that the majority of undernourished adults in developing countries are women. Indeed, most publications from developing countries report low energy intakes of women, particularly during pregnancy and lactation. The high incidence of low birth weight and growth faltering at an early age have been attributed to maternal undernutrition. While there is no disagreement about the adverse effects of acute and severe energy deficits on the outcome of pregnancy and lactation (Stein et al. 1975; Prentice, 1980), no consensus has yet been reached on the relationship between maternal nutrition and reproductive performance in communities having marginal energy intakes either seasonally or chronically (Rush, 1983; National Academy of Sciences, $1990,1991)$. Maternal depletion over the course of numerous reproduction cycles is an often hypothesized but little measured phenomenon (Merchant et al. 1990a,b).

Results of recent studies indicate that, in industrialized countries, healthy pregnant and lactating women who can eat to appetite do not increase their dietary energy intake to the degree recommended (World Health Organization, 1985), with no resulting impairment of their reproductive function (Whitehead et al. 1981; Durnin, 1987; National Academy of Sciences, 1990; van Raaij et al. 1991). The longitudinal study on energy requirements of apparently healthy pregnant women which included three developing countries (The Philippines, Thailand, The Gambia) did not show a consistent pattern of reproductive physiology (Durnin, 1987). The main problem lies in the concept of 'apparently healthy'. On the other hand, the extra energy requirement during lactation in developing countries may approach the dietary recommendation (Frigerio et al. 1991; Madhavapeddi \& Rao, 1992).

The calculated energy requirements in pregnancy and lactation (World Health Organization, 1985) or observed energy intakes of apparently healthy women in industrialized countries bear little relationship to the needs of many Third World women who are poorly nourished to start with. For practical purposes it is more relevant to assess at which level of maternal energy status, child and maternal outcomes of reproduction are compromised.

Studies in The Gambia show that seasonal fluctuations in energy intake were reflected in concomitant weight changes of pregnant and lactating women, mean birth weight and the quantity and quality of breast milk were reduced, the incidence of low birth weight increased (Prentice, 1980). The improvement of energy intake and the replenishment of body fat during the period of abundance was not sufficient to subsidize the whole of a 
reproductive cycle in the lean period. Subsequent studies have produced evidence of a remarkable mechanism for coping with the extreme seasonal fluctuations in energy intake by an overall mobilization of body fat, a reduction of BMR and a reduction in physical activity towards the end of pregnancy (Prentice, 1984; Prentice \& Whitehead, 1987).

In most areas with rain-dependent agriculture, seasonal fluctuations in energy balance may be less profound than in areas like The Gambia. To my knowledge, no published information is available of the repercussions of such seasonal stress on maternal nutrition during pregnancy and lactation. In a study of non-pregnant women the energy deficit during the lean season was compensated by losing weight and/or a reduction of BMR and/or a reduction of physical activities (Durnin, 1990: Ferro-Luzzi, 1990).

Some distinguished researchers claim that energy requirements for reproduction are relatively low and can be compensated by protective mechanisms such as lower BMR and reduced physical activity (Naismith, 1981; Prentice \& Whitehead, 1987). Shetty (1990) in his review of energy metabolism in adults with low body weight and low body mass index (weight/height ${ }^{2}$; BMI) concluded, however, that meaningful adaptive responses in energy expenditure could not be demonstrated. Increased metabolic efficiency in the BMR component of energy expenditure in such subjects may just be an illustration of decreased active tissue due to a change in body composition in response to chronic energy deficiency. Gopalan (1990) rightly states that a reduction in physical activity only maintains the low productivity and quality of life among populations in energy balance with their present poor diets.

The functional meaning of metabolic adjustments to seasonal hunger depends on whether or not such periods are superimposed on an already chronically-energy-deficient condition. Assuming that the degree of maternal undernutrition determines maternal response to reproductive stress, the recently introduced concept of chronic energy deficiency (CED) can be used in the analytical framework.

CED is defined as 'a steady state at which a person is in energy balance although at a cost, either in terms of risk to health or as an impairment of functions and health . . . (James et al. 1988). Originally, the combined use of the physical activity level (PAL) as proxy for energy expenditure and BMI as proxy for energy reserves was suggested as criteria of CED. Later evidence showed that PAL was an unnecessary extra criterion, leaving BMI as the only indicator for CED (Ferro-Luzzi et al. 1992). Three grades of BMI were suggested to categorized CED as mild, moderate and severe, i.e. $17 \cdot 0-18 \cdot 4$ (grade I), 16.0-16.9 (grade II) and less than $16 \cdot 0$ (grade III). Limited data from India suggest the same functional significance of BMI in adults as anthropometric indicators in young children. Among men lower BMI was related to higher mortality (Satyanaraya et al. 1991) and there was a remarkably close relationship between $24 \mathrm{~h}$ post-partum BMI categories and low birth weight (Naidu et al. 1991).

More information is needed to justify a definition of CED based on BMI for pregnant and lactating women. Data from a longitudinal study on maternal nutrition and reproduction in Madura, East Java will be used to address this issue.

\section{CED IN PREGNANT AND LACTATING WOMEN IN EAST JAVA}

The longitudinal study, known as the East Java Pregnancy Study (EJPS), was conducted in a rural community on the island of Madura, East Java province in the years 1981-89. 
Details of the study population and methodology of data collection have been described in earlier publications (Kardjati et al. 1988, 1990; van Steenbergen et al. 1989; Kusin et al. 1990).

In summary, the study villages are located in a semi-arid zone along the coast. Mild seasonal fluctuations in energy intake of pregnant women were observed, the range between lean and harvest season being on average 6.3-7.1 MJ (1500-1700 kcal)/d.

As in any subsistence economy women are housewives and productive labourers. The activity records indicate that women were at most only moderately active. Irrespective of physiological state only $5-15 \%$ of the day $(1-3 \mathrm{~h}$ ) was spent on strenuous work, such as working in the fields, carrying large baskets of fish to the market, fetching water or collecting fodder. Thus, the level of physical activity would correspond to 1.5-1.7 $\times$ BMR (World Health Organization, 1985).

The framework of EJPS was a surveillance of all mothers with children aged 0-60 months and newly married couples. They were visited at home at four-weekly intervals to detect a pregnancy and to monitor growth of babies born in the study. On these occasions all women were weighed to provide prepregnant weight. Once a woman was found to be pregnant, she was asked to come to the antenatal clinic at four-weekly intervals for an obstetric examination. Birth weight was measured within $24 \mathrm{~h}$ after delivery. After delivery, the mother-infant pair was taken up in the surveillance system which ensured the measurement of mother's postpartum weight as well as infant's weight and length till the child was 12 months old.

In the first 3 years pregnant women were studied intensively. Anthropometric measurements were taken (height, weight, skinfold thickness at four sites, upper arm circumference). Their food consumption was measured, once in early pregnancy and monthly in the last trimester by the weighing technique over three consecutive days (Launer et al. 1991).

Data from women who had given birth to a single liveborn baby in the period September 1982-December 1989 in two study villages were analysed.

\section{Prepregnant weight by height and BMI}

A total of 972 women had given birth to 1782 single liveborn babies. Women were small (average height $1.50 \mathrm{~m}$ ) and lean (average weight $42 \mathrm{~kg}$ ). About $40 \%$ had a prepregnant weight of less than $42 \mathrm{~kg}$. Mean BMI increases with weight and there was no relationship with height (Table 1). In fact, a very large percentage of women weighing less than $45 \mathrm{~kg}$ had a BMI below 18.5 and can be considered CED (Table 2). Of the total sample $2.6 \%$ can be categorized as severe CED, $10.3 \%$ as moderate CED and $28.4 \%$ as mild CED (not shown in Table).

The prevalence of CED was not related to parity and birth interval. The range was $51 \%$ for parity 1 to $28 \%$ for parity $7+$ and $31 \%$ for birth interval less than 18 months to $28 \%$ for birth interval more than 27 months. There was no indication that women were not yet mature when they became pregnant for the first time.

These findings suggest that women of reproductive age were chronically undernourished initially. Thus, it is more likely that the degree of undernutrition will influence reproductive performance and probably fecundity rather than reproduction leading to maternal depletion. 
Table 1. Prepregnant body mass index (weight/height ${ }^{2} ; B M I$ ) in relation to prepregnant weight and height categories for East Javanese women giving birth to single liveborn babies*

(Mean values and standard deviations; $n 1089$ single live births)

\begin{tabular}{|c|c|c|c|c|c|c|c|c|c|c|c|c|}
\hline \multirow{3}{*}{$\begin{array}{l}\text { Prepregnant } \\
\text { wt }(\mathrm{kg})\end{array}$} & \multicolumn{10}{|c|}{ Height (m) } & & \\
\hline & \multicolumn{2}{|c|}{$<1.45$} & \multicolumn{2}{|c|}{$1 \cdot 45-1.49$} & \multicolumn{2}{|c|}{$1 \cdot 50-1 \cdot 54$} & \multicolumn{2}{|c|}{$1.55-1.59$} & \multicolumn{2}{|c|}{$\geqslant 1 \cdot 60$} & \multicolumn{2}{|c|}{ BMI total } \\
\hline & Mean & $\mathrm{SD}$ & Mean & $\mathrm{SD}$ & Mean & $\mathrm{SD}$ & Mean & SD & Mean & $\mathrm{SD}$ & Mean & SD \\
\hline$<42$ & $18 \cdot 7$ & $1 \cdot 2$ & $17 \cdot 8$ & $1 \cdot 1$ & $17 \cdot 0$ & 0.9 & $16 \cdot 4$ & 0.6 & $16 \cdot 2$ & $-\dagger$ & $17 \cdot 7$ & $1 \cdot 2$ \\
\hline $42-44.9$ & 21.0 & 0.8 & $19 \cdot 8$ & 0.5 & $18 \cdot 6$ & 0.5 & $17 \cdot 6$ & 0.5 & $16 \cdot 8$ & $-t$ & $19 \cdot 1$ & $1 \cdot 1$ \\
\hline $45-48 \cdot 9$ & $22 \cdot 3$ & 0.6 & $21 \cdot 2$ & 0.6 & $19 \cdot 8$ & 0.6 & $18 \cdot 8$ & 0.5 & $18 \cdot 2$ & 0.5 & $20 \cdot 0$ & $1 \cdot 2$ \\
\hline$\geqslant 49 \ddagger$ & - & - & $23 \cdot 0$ & 0.5 & $21 \cdot 4$ & 0.5 & $20 \cdot 4$ & 0.6 & $19 \cdot 7$ & 0.5 & $22 \cdot 2$ & $2 \cdot 0$ \\
\hline BMI total & $19 \cdot 4$ & $1 \cdot 7$ & $19 \cdot 2$ & $2 \cdot 0$ & $19 \cdot 0$ & $2 \cdot 0$ & $18 \cdot 7$ & 1.9 & $19 \cdot 3$ & $2 \cdot 0$ & $19 \cdot 1$ & 1.9 \\
\hline
\end{tabular}

* East Java Pregnancy Study (Kardjati et al. 1988, 1990; van Steenbergen et al. 1989; Kusin et al. 1990).

$\dagger$ One subject only.

$\pm 49-53 \mathrm{~kg}$.

Table 2. Percentage of chronic energy deficiency* relative to categories of prepregnant weight and height (percentages of total) for East Javanese women giving birth to single liveborn babies $\dagger$

\begin{tabular}{|c|c|c|c|c|c|c|}
\hline \multirow{2}{*}{$\begin{array}{l}\text { Prepregnant } \\
\text { wt (kg) }\end{array}$} & \multicolumn{5}{|c|}{ Height (m) } & \multirow{2}{*}{$\begin{array}{l}\text { Percentage of } \\
\text { wt category }\end{array}$} \\
\hline & $<1.45$ & $1.45-1.49$ & $1 \cdot 50-1 \cdot 54$ & $1.55-1.59$ & $\geqslant 1 \cdot 60$ & \\
\hline$<42$ & $4 \cdot 0$ & $13 \cdot 0$ & $10 \cdot 1$ & $1 \cdot 8$ & $0 \cdot 1$ & 73 \\
\hline $42-44 \cdot 9$ & - & - & 3.9 & $3 \cdot 5$ & 0.1 & 29 \\
\hline $45-48 \cdot 9$ & - & - & - & $1 \cdot 1$ & 0.6 & 7 \\
\hline$\geqslant 49$ & - & - & - & - & - & - \\
\hline $\begin{array}{l}\text { Percentage of } \\
\text { height category }\end{array}$ & 30 & 36 & 41 & 48 & 35 & 38 \\
\hline
\end{tabular}

* Body mass index (weight/height $\left.{ }^{2}\right)<18 \cdot 5$.

$\dagger$ East Java Pregnancy Study (Kardjati et al. 1988, 1990; van Steenbergen et al. 1989; Kusin et al. 1990).

\section{The period of pregnancy}

On average home diets contributed 6.7 MJ and $42 \mathrm{~g}$ protein/d (Launer et al. 1991). Energy intake would correspond to $1.6 \times$ BMR for non-pregnant, non-lactating women of $42 \mathrm{~kg}$ weight.

Total weight gain in pregnancy was on average $6.6 \mathrm{~kg}$. Compared with well-nourished British women (Taggart et al. 1967) skinfold thicknesses of Madurese women were much lower, about $50 \%$ lower at the triceps and biceps sites and 15-20\% lower at the subscapula and suprailiac sites (Kardjati et al. 1990). The difference in BMI before pregnancy and at 4-7 weeks post partum illustrates the net weight gain in pregnancy (Table 3). There was a clear and differential response to reproductive stress by BMI 
Table 3. Changes in body mass index (weight/height ${ }^{2} ; B M I$ ) over pregnancy in relation to categories of prepregnant BMI for East Javanese women giving birth to single liveborn babies*

(Mean values and standard deviations)

\begin{tabular}{|c|c|c|c|c|c|c|c|}
\hline \multirow{3}{*}{$\begin{array}{l}\text { Prepregnant } \\
\text { BMI }\end{array}$} & \multirow[b]{3}{*}{$n$} & \multicolumn{4}{|c|}{ BMI } & \multirow{2}{*}{\multicolumn{2}{|c|}{$\begin{array}{c}\text { Change in BMI } \\
4 \text { weeks post partum } \\
\text { minus prepregnant }\end{array}$}} \\
\hline & & \multicolumn{2}{|c|}{ Prepregnant } & \multicolumn{2}{|c|}{$\begin{array}{c}4 \text { weeks post } \\
\text { partum }\end{array}$} & & \\
\hline & & Mean & SD & Mean & $\mathrm{SD}$ & Mean & SD \\
\hline$<16$ & 23 & $15 \cdot 3$ & 0.7 & $16 \cdot 6$ & 1.6 & $+1 \cdot 3^{a}$ & 1.6 \\
\hline $16-16 \cdot 9$ & 64 & $16 \cdot 6$ & $0 \cdot 3$ & $17 \cdot 7$ & $1 \cdot 1$ & $+1 \cdot 1^{\mathrm{a}}$ & $1 \cdot 0$ \\
\hline $17-18 \cdot 4$ & 192 & $17 \cdot 2$ & 0.4 & $18 \cdot 6$ & $1 \cdot 0$ & $+0 \cdot 8^{b}$ & 1.0 \\
\hline$\geqslant 18.5$ & 429 & $20 \cdot 2$ & 1.6 & $20 \cdot 2$ & $1 \cdot 7$ & $0.0^{c}$ & $1 \cdot 4$ \\
\hline All & 708 & $19 \cdot 1$ & 1.9 & $19 \cdot 4$ & 1.8 & $+0 \cdot 3$ & $1 \cdot 3$ \\
\hline
\end{tabular}

a,b,c Mean values with unlike superscript letters were significantly different: a,b $P<0 \cdot 001$, b,c $P<0 \cdot 01$.

* East Java Pregnancy Study (Kardjati et al. 1988, 1990; van Steenbergen et al. 1989; Kusin et al. 1990).

categories. CED mothers (BMI less than 18.5 and prepregnant weight less than $42 \mathrm{~kg}$ ) gained weight during pregnancy. Non-CED mothers did not lose weight but they also did not build up fat reserves.

\section{Prepregnant BMI and fetal growth}

In view of the weight changes during pregnancy, one can reasonably assume that the habitual dietary energy intake was not sufficient to support adequate fetal growth, and maternal energy reserves before pregnancy would be crucial. Table 4 shows that the relationship between prepregnant BMI and fetal growth. There was an upward gradient in mean birth weight with increasing prepregnant BMI and a corresponding decrease in

Table 4. Birth weight and incidence of low birth weight (LBW) in relation to categories of prepregnant body mass index (weight/height ${ }^{2} ; B M I$ ) in East Javanese women giving birth to single liveborn babies*

(Mean values and standard deviations)

\begin{tabular}{|c|c|c|c|c|}
\hline \multirow{2}{*}{$\begin{array}{l}\text { Prepregnant } \\
\text { BMI }\end{array}$} & \multirow[b]{2}{*}{$n$} & \multicolumn{2}{|c|}{ Birth wt } & \multirow{2}{*}{$\begin{array}{c}\text { Percentage LBW } \\
(<2500 \mathrm{~g})\end{array}$} \\
\hline & & Mean & $\mathrm{SD}$ & \\
\hline$<16$ & 28 & $2729^{a}$ & 332 & $21^{\mathrm{d}}$ \\
\hline $16-16.9$ & 94 & $2859^{a}$ & 343 & $10^{d}$ \\
\hline $17-18 \cdot 4$ & 266 & $2941^{b}$ & 380 & $8^{e}$ \\
\hline$\geqslant 18 \cdot 5$ & 608 & $3025^{c}$ & 358 & $5^{e}$ \\
\hline All & 996 & 2978 & 368 & 7 \\
\hline
\end{tabular}

$a, b, c, d, e$ Mean values in vertical columns with unlike superscript letters were significantly different: a,b $P<0.001$, b,c $P<0.01$, d.e $P<0.003$.

* East Java Pregnancy Study (Kardjati et al. 1988, 1990; van Steenbergen et al. 1989; Kusin et al. 1990). 
Table 5. Body mass index (weight/height ${ }^{2} ; B M I$ ) in the first year post partum in relation to categories of weight at 4 weeks post partum for East Javanese women giving birth to single liveborn babies $\ddagger$

(Mean values and standard deviations)

\begin{tabular}{|c|c|c|c|c|c|c|c|c|c|c|c|c|}
\hline \multirow{3}{*}{$\begin{array}{l}\text { Mother's wt }(\mathrm{kg}) 4-7 \\
\text { weeks post partum } \ldots \\
\text { Period post partum } \\
\text { (months) }\end{array}$} & \multicolumn{12}{|c|}{$\mathrm{BMI}$} \\
\hline & \multicolumn{2}{|c|}{$<36$} & \multicolumn{2}{|c|}{$36-37.9$} & \multicolumn{2}{|c|}{$38-41.9$} & \multicolumn{2}{|c|}{$42-49 \cdot 9$} & \multicolumn{2}{|c|}{$\geqslant 50$} & \multicolumn{2}{|c|}{ All } \\
\hline & Mean & SD & Mean & SD & Mean & SD & Mean & $\mathrm{SD}$ & Mean & SD & Mean & $\mathrm{SD}$ \\
\hline 1 & $16 \cdot 3^{*} \dagger$ & 1.4 & $17 \cdot 4$ & 0.9 & $18 \cdot 3$ & $1 \cdot 0$ & $19 \cdot 8$ & $1 \cdot 3$ & $22 \cdot 6$ & $1 \cdot 8$ & $19 \cdot 4$ & 1.9 \\
\hline 3 & $16 \cdot 5^{* \dagger}+$ & $1 \cdot 4$ & $17 \cdot 6$ & 1.0 & $18 \cdot 3$ & $1 \cdot 1$ & $19 \cdot 8$ & $1 \cdot 3$ & $22 \cdot 5$ & 1.9 & $19 \cdot 4$ & 1.9 \\
\hline 6 & $16 \cdot 8^{* \dagger}$ & 1.7 & $17 \cdot 6$ & $1 \cdot 1$ & $18 \cdot 2$ & $1 \cdot 2$ & $19 \cdot 6$ & 1.4 & $22 \cdot 2$ & $2 \cdot 2$ & $19 \cdot 3$ & 1.9 \\
\hline 12 & $17.5^{* \dagger} \dagger$ & $2 \cdot 1$ & $17 \cdot 8$ & 1.2 & $18 \cdot 3$ & 1.4 & $19 \cdot 5$ & 1.5 & 21.8 & $2 \cdot 1$ & $19 \cdot 2$ & 1.9 \\
\hline
\end{tabular}

Mean values for $<36 \mathrm{~kg}$ group were significantly different from those for $36-37.9 \mathrm{~kg}: * P<0.05$.

Mean values for $<36 \mathrm{~kg}$ group were significantly different from those for all other groups $(\equiv 36 \mathrm{~kg}): \dagger P<0 \cdot 001$.

$\ddagger$ East Java Pregnancy Study (Kardjati et al. 1988, 1990; van Steenbergen et al. 1989; Kusin et al. 1990).

the incidence of low birth weight. A very high incidence of low birth weight $(21 \%)$ was only observed in the severe CED group, but the incidence in the other CED groups was still two times higher than that in the non-CED group.

\section{Mothers' weight changes in the first 12 months post partum}

Breast feeding is a natural process in the Madurese community and the median duration of lactation is $18-24$ months. Daily energy intake during lactation was about $0.8 \mathrm{MJ} / \mathrm{d}$ higher than that during pregnancy, while activity levels were similar across physiological states (J. A. Kusin, Sri Kardjati and U. H. Renqvist, unpublished results). The average weight loss in the first 12 months post partum was $0.7 \mathrm{~kg}$, but the variation was large. The pattern of weight changes in the first year after birth by categories of 4-7 weeks postpartum weight was similar to that over pregnancy (Table 5). The severe CED women gained weight $(2.5 \mathrm{~kg})$, so did the moderate CED group, but much less $(0.8 \mathrm{~kg})$, and the non-CED group lost weight $(0 \cdot 8 \mathrm{~kg})$.

\section{Infant growth in the first year}

If weight gain in CED women during lactation reflects a repletion of her own energy stores, one may expect reduced breast milk production and poor growth of their infants. Unfortunately it is customary to force-feed infants from as early as the first week after birth, although the semi-solid additional food (mashed rice and banana) does not influence milk production (van Steenbergen et al. 1991). Thus, infants' growth may be a crude proxy of breast milk intake. To adjust for birth weight, infant growth is presented in two categories with the mean birth weight $(2800 \mathrm{~g})$ of infants of the severe and moderate CED women as the cut-off point. Table 6 illustrates the expected upward gradient in weight increment with increasing BMI of mothers. The differences between the groups whose maternal prepregnant BMI were below 17 and the groups with higher maternal prepregnant BMI was significant only for the higher birth weight category. The 
Table 6. Postnatal growth of infants according to mother's prepregnant body mass index (weight/height ${ }^{2}$; BMI) for East Javanese women giving birth to single liveborn babies $\dagger$

(Mean values and standard deviations; nos. at birth adapted to nos. at 3 months)

\begin{tabular}{|c|c|c|c|c|c|c|c|c|}
\hline \multirow[t]{2}{*}{ Mothers' BMI . . . } & \multicolumn{2}{|c|}{$<17$} & \multicolumn{2}{|c|}{$17-18 \cdot 4$} & \multicolumn{2}{|c|}{$\geqslant 18.5$} & \multicolumn{2}{|c|}{ All } \\
\hline & Mean & SD & Mean & SD & Mean & SD & Mean & SD \\
\hline \multicolumn{9}{|l|}{ Birth wt $<2800$} \\
\hline$n$ & \multicolumn{2}{|c|}{16} & \multicolumn{2}{|c|}{64} & \multicolumn{2}{|c|}{93} & \multicolumn{2}{|c|}{173} \\
\hline Birth wt & 2577 & 185 & 2483 & 218 & 2553 & 176 & 2519 & 203 \\
\hline Wt gain $0-12$ months & 5100 & 585 & 5325 & 1043 & 5412 & 928 & 5345 & 928 \\
\hline \multicolumn{9}{|l|}{ Birth wt $\geqslant 2800$} \\
\hline$n$ & \multicolumn{2}{|c|}{27} & \multicolumn{2}{|c|}{125} & \multicolumn{2}{|c|}{378} & \multicolumn{2}{|c|}{517} \\
\hline Birth wt & 2981 & 168 & 3104 & 225 & 3142 & 260 & 3131 & 256 \\
\hline Wt gain $0-12$ months & $4558^{*}$ & 803 & 4909 & 861 & 4932 & 930 & 4896 & 909 \\
\hline
\end{tabular}

Mean value was significantly different from those for all other groups: $* P<0 \cdot 05$.

† East Java Pregnancy Study (Kardjati et al. 1988, 1990; van Steenbergen et al. 1989; Kusin et al. 1990).

lower weight increments in this category are difficult to explain; it is tempting to attribute them to substrate limitation of milk production to a level insufficient for the bigger babies. One can at least conclude that infants born to CED women are not 'in the driving seat' with respect to determining energy intake according to their needs.

\section{FOOD FOR THOUGHT}

Maternal nutrition has been studied in relation to fetal growth, lactation and infant growth but the effect of reproduction on women's nutritional status has received limited attention (Krasovec \& Anderson, 1991). There is evidence that pregnant and lactating women can be in energy balance on surprisingly low energy intakes, admittedly 'not always compatible with an optimum quality of life' (Prentice, 1984). An understanding of the limits of the maternal body to support fetal and infant growth without depleting her own energy reserves is a condition for any intervention programme to promote the well-being of mother and infant.

In the population for our study the cut-off point in BMI of 18.5 did differentiate women in terms of maternal and infant outcomes of reproduction. The high prevalence of CED before the first pregnancy suggests that undernutrition among women of reproductive age is primarily a result of low energy intakes. In such a situation it is more likely that undernutrition will influence reproductive performance rather than reproduction having an adverse effect on maternal energy status.

Prepregnant weight and BMI was found to determine maternal response to reproductive stress in such a way that pregnancy and lactation appear to promote weight gain in chronically undernourished women to the detriment of fetal and infant growth. Contrary to conventional wisdom, maternal weight gain during pregnancy and lactation among Madurese women was an indication of a poor maternal energy status and predictive of a poor reproductive outcome!

There are very few studies for comparison. In The Gambia there was evidence of a competition between repletion of maternal subcutaneous fat and milk production in 
undernourished lactating women (Paul et al. 1979) and being pregnant appears to benefit a woman's own energy balance (Durnin, 1987). Most comparable to our study is that of Winkvist (1992). She examined weight changes over two consecutive pregnancies among Pakistani women and did a secondary analysis of data from the well-known supplementation study in Guatemala. The net weight change during one reproductive cycle was defined as the difference in 1-3 months postpartum weight of two consecutive pregnancies. The largest positive maternal weight gain and the highest negative difference in mean birth weight between two consecutive births was observed in the low initial weight group. In a comparable study in the Philippines weight changes during lactation did not differ across the range of postpartum weight and BMI, although maternal weight and height distribution was similar to that in East Java (Adair et al. 1990).

Through which processes would CED women replete their energy stores at the expense of the fetus and infant? The homeostatic mechanism that regulates the partitioning of dietary energy during reproduction and growth in the human are poorly understood. Quantitative aspects of the partitioning of nutrients between mother and offspring have been extensively studied in animal sciences. Compartmentalization to protect maternal health seems to depend on previous maternal nutritional status (Glore \& Layman, 1985; Young \& Rasmussen, 1985; Sadurskis et al. 1991). Work still remains to be done on the relationship between maternal nutrition and weight gain and the outcome at birth in humans. Path models, used to analyse the effect of the famine of the 1944-5 winter in The Netherlands suggest that under famine conditions there may be a shift in the role of the placenta in the passage of nutrients from the mother to the fetus to the advantage of the mother (Susser, 1991).

Whatever the mechanisms underlying the preferential partitioning of energy to the CED mother, they may explain the modest effect or absence of an effect of energy supplementation to undernourished pregnant and lactating mothers. Additional criteria for selection of beneficiaries (level of maternal BMI) and maternal indicators for evaluation of impact are needed.

Communities in developing countries are not homogenous and the observations in one area will certainly not have a universal validity. Nevertheless one can conclude that weight monitoring of mothers is as essential as growth monitoring of young children. Indeed, by concentrating entirely on child malnutrition, one has distorted the picture of food needs in developing countries (Ferro-Luzzi et al. 1992). The Safe Motherhood Initiative, designed to reduce maternal mortality, is too limited to address the problem of maternal ill health and undernutrition.

\section{REFERENCES}

Adair, L. S., Popkin, B. M., Bisgrove, E. Z. \& Barba, C. (1990). A longitudinal analysis of patterns and determinants of women's diets and nutritional status in the Philippines. Maternal Nutrition and Health Care Program Research Report Series no. 1. Washington, DC: International Center for Research on Women.

Durnin, J. V. G. A. (1987). Energy requirements of pregnancy: an integration of the longitudinal data from the five country study. Lancet ii, 1131-1133.

Durnin, J. V. G. A. (1990). Low energy expenditures in free-living populations. European Journal of Clinical Nutrition 44, Suppl. 1, 95-102.

Ferro-Luzzi, A. (1990). Seasonal energy stress in marginally nourished rural women: interpretation and integrated conclusions of a multicentre study in three developing countries. European Journal of Clinical Nutrition 44, Suppl. 1, 41-46.

Ferro-Luzzi, A., Sette, S., Franklin, M. \& James, W. P. T. (1992). A simplified approach of assessing adult energy deficiency. European Journal of Clinical Nutrition 46, 173-186. 
Food and Agriculture Organization (1990). The State of Food and Agriculture. World and Regional Reviews, Structural Adjustment and Agriculture, pp. 30-33, Rome: FAO.

Frigerio, C., Schutz, Y., Prentice, A., Whitehead, R. G. \& Jéquier, E. (1991). Is human lactation a particularly efficient process? European Journal of Clinical Nutrition 45, 969-982.

Glore, S. R. \& Layman, D. K. (1985). Loss of tissues in female rats subjected to food restriction during lactation and during both gestation and lactation. Journal of Nutrition 115, 233-242.

Gopalan, C. (1990). Low energy intakes. Bulletin of Nutrition Foundation of India 11, 5-6.

James, W. P. T., Ferro-Luzzi, A. \& Waterlow, J. C. (1988). Definition of chronic energy deficiency in adults. Report of a Working Group Party of the International Dietary Energy Consultative Group. European Journal of Clinical Nutrition 42, 969-982.

Kardjati Sri, Kusin, J. A. \& de With, C. (1988). Energy supplementation in the last trimester of pregnancy in East Java: I. Effect on birth weight. British Journal of Obstetrics and Gynaecology 95, 783-794.

Kardjati Sri, Kusin, J. A., Schofield, W. M. \& de With, C. (1990). Energy supplementation in the last trimester of pregnancy in East Java, Indonesia: Effect on maternal anthropometry. American Journal of Clinical Nutrition 52, 987-994.

Krasovec, K. \& Anderson, M. A. (1991). Maternal nutrition and pregnancy outcomes. Pan American Health Organization Scientific Publication no. 529. Washington, DC: Pan American Health Organization.

Kusin, J. A., Kardjati Sri, de With, C. \& van Steenbergen, W. M. (1990). The East Java Pregnancy Study: Effect of prenatal supplementation on mother and infant. In Child Nutrition in South-East Asia, pp. 63-88 [H. K. A. Visser and J. G. Bindels, editors]. Dordrecht: Kluwer Academic Publishers.

Launer, L. J., Kardjati Sri, Kusin, J. A. \& Reed, G. F. (1991). Patterns of variability in the nutrient intake of nutritionally vulnerable pregnant women. European Journal of Clinical Nutrition 45, 131-138.

McGuire, J. \& Popkin, B. M. (1989). Beating the zero sum game: women and nutrition in the Third World. UNU Food and Nutrition Bulletin 11, 38-63.

Madhavapeddi, R. \& Rao, B. S. N. (1992). Energy balance in lactating undernourished Indian women. European Journal of Clinical Nutrition 46, 349-354.

Merchant, K., Martorell, R. \& Haas, J. (1990a). Maternal and fetal responses to the stresses of lactation, concurrent with pregnancy and short recuperation intervals. American Journal of Clinical Nutrition 52, 280-288.

Merchant, K., Martorell, R. \& Haas, J. (1990b). Consequences for maternal nutrition of reproductive stress across consecutive pregnancies. American Journal of Clinical Nutrition 52, 616-620.

Naidu, A. N., Neela, J. \& Rao, N. P. (1991). Maternal body mass index and birth weight. Nutrition News, Hyderabad 12, 1

Naismith, D. J. (1981). Diet during pregnancy - a rationale for prescription. In Maternal Nutrition During Pregnancy - Eating for Two?, pp. 21-31 [J. Dobbing, editor]. New York; Academic Press.

National Academy of Sciences (1990). Nutrition During Pregnancy. Washington, DC: National Academy Press.

National Academy of Sciences (1991). Nutrition During Lactation. Washington, DC: National Academy Press.

Paul, A. A., Mueller, E. M. \& Whitehead, R. G. (1979). The quantitative effects of maternal dietary intake on pregnancy and lactation. Transactions of the Royal Society of Medicine and Hygiene 73, 686-692.

Prentice, A. M. (1980). Variations in maternal dietary intake, birth weight and breast-milk output in the Gambia. In Maternal Nutrition During Pregnancy and Lactation, pp. 167-183 [H. Aebi and R. G. Whitehead, editors]. Bern: Hans Huber Publishers.

Prentice, A. M. (1984). Adaptations to long-term low energy intake. In Energy Intake and Activity, pp. 3-33 [E. Pollitt and P. Amante, editors]. New York: Alan Liss Inc.

Prentice, A. M. \& Whitehead, R. G. (1987). The energetics of human reproduction. Symposium of the Zoological Society, London 57, 257-304.

Rush, D. (1983). Effects of protein and calorie supplementation during pregnancy on the fetus and developing child. In Nutrition in Pregnancy, pp. 65-81 [D. M. Campbell and M. D. G. Gilmer, editors]. London: Royal College of Obstetricians and Gynaecologists.

Sadurskis, A., Sohlström, A., Kabir, N. \& Forsum, E. (1991). Energy restriction and partitioning of energy between costs of reproduction in rats. Journal of Nutrition 112, 1798-1810.

Satyanarayana, K., Rao, S. S., Radhial, G. \& Reddy, V. (1991). Body mass index and mortality rates. Nutrition News, Hyderabad 12, 2.

Shetty, P. S. (1990). Energy metabolism in chronic energy deficiency. Proceedings of the Nutrition Society of India 36, 89-97. 
Stein, Z., Susser, M., Saenger, G. \& Marolla, F. (1975). Famine and Human Development: The Dutch Hunger Winter of 1944/5. New York: Oxford University Press.

Susser, M. (1991). Maternal weight gain, infant birth weight and diet: causal sequences. American Journal of Clinical Nutrition 53, 1384-1396.

Taggart, N. R., Holliday, R. M., Billewics, W. Z., Hytten, F. E. \& Thomson, A. M. (1967). Changes in skinfolds during pregnancy. British Journal of Nutrition 21, 439-451.

van Raaij, J. M. A., Schonk, C. M., Vermaat-Miedema, S. H., Peek, M. E. M. \& Hautvast, J. G. A. J. (1991). Energy cost of lactation and energy balances of well-nourished Dutch lactating women: a reappraisal of the extra energy requirements of lactation. American Journal of Clinical Nutrition 53, 612-619.

van Steenbergen, W. M., Kusin, J. A., Kardjati Sri \& de With, C. (1989). Energy supplementation in the last trimester of pregnancy in East Java: Effect on breast milk output. American Journal of Clinical Nutrition 50, 274-279.

van Steenbergen, W. M., Kusin, J. A., Kardjati Sri \& Renqvist, U. H. (1991). Nutritional transition during infancy in East Java: a longitudinal study of breast milk intake and the consumption of additional foods.

Whitehead, R. G., Paul, A. A., Black, A. E. \& Wiles, S. J. (1981). Recommended dietary amounts of energy for pregnancy and lactation in the United Kingdom. In Protein-energy Requirements of Developing Countries: Evaluation of New Data UNU Food and Nutrition Bulletin, Suppl. 5 [B. Torun, V. R. Young and W. M. Rand, editors]. Tokyo: UNU.

Winkvist, A. (1992). Maternal depletion among Pakistani and Guatemalan women. PhD Thesis, Cornell University.

World Health Organization (1985). Energy and Protein Requirements. Report of a Joini FAO/WHO/UNU Expert Consultation. Technical Report Series no. 724. Geneva: WHO.

Young, C. M. \& Rasmussen, K. M. (1985). Effects of varying degrees of chronic dietary restriction in rat dams on reproductive and lactational performance and body composition in dams and their pups. American Journal of Clinical Nutrition 41, 979-987. 